\title{
Experiment End Date
}

National Cancer Institute

\section{Source}

National Cancer Institute. Experiment End Date. NCI Thesaurus. Code C90382.

The date on which an experiment concludes. 